OPEN ACCESS

Edited by:

Om V. Singh,

Technology Sciences Group Inc,

United States

Reviewed by:

Dario De Medici,

Istituto Superiore di Sanità (ISS), Italy

Pendru Raghunath,

Texila American University, Guyana

${ }^{*}$ Correspondence:

Xianming Shi

xmshi@sjtu.edu.cn

Specialty section:

This article was submitted to

Food Microbiology,

a section of the journal

Frontiers in Microbiology

Received: 15 August 2018

Accepted: 26 March 2019

Published: 05 April 2019

Citation:

Bai Y, Cui Y, Suo Y, Shi C,

Wang $D$ and Shi $X$ (2019) A Rapid

Method for Detection of Salmonella in

Milk Based on Extraction of mRNA

Using Magnetic Capture

Probes and RT-qPCR

Front. Microbiol. 10:770.

doi: 10.3389/fmicb.2019.00770

\section{A Rapid Method for Detection of Salmonella in Milk Based on Extraction of mRNA Using Magnetic Capture Probes and RT-qPCR}

\author{
Yalong Bai ${ }^{1,2}$, Yan Cui ${ }^{1}$, Yujuan Suo ${ }^{2}$, Chunlei Shi ${ }^{1}$, Dapeng Wang ${ }^{1}$ and Xianming Shi* \\ ${ }^{1}$ MOST-USDA Joint Research Center for Food Safety, School of Agriculture and Biology and State Key Laboratory of \\ Microbial Metabolism, Shanghai Jiao Tong University, Shanghai, China, ²Institute for Agri-food Standards and Testing \\ Technology, Shanghai Academy of Agricultural Sciences, Shanghai, China
}

Magnetic separation is an efficient method for target enrichment and elimination of inhibitors in the molecular detection systems for foodborne pathogens. In this study, we prepared magnetic capture probes by modifying oligonucleotides complementary to target sequences on the surface of amino-modified silica-coated magnetic nanoparticles and optimized the conditions and parameters of probe synthesis and hybridization. We innovatively put the complexes of magnetic capture probes and target sequences into qPCR without any need for denaturation and purification steps. This strategy can reduce manual steps and save time. We used the magnetic capture probes to separate invA mRNA from Salmonella in artificially contaminated milk samples. The detection sensitivity was $10^{4} \mathrm{CFU} / \mathrm{ml}$, which could be increased to $10 \mathrm{CFU} / \mathrm{ml}$ after a $12 \mathrm{~h}$ enrichment step. The developed method is robust enough to detect live bacteria in a complex environmental matrix.

Keywords: amino-modified silica-coated magnetic nanoparticles, magnetic capture probes, Salmonella, RT-qPCR, milk

\section{INTRODUCTION}

Magnetic nanoparticles and especially immunomagnetic nanoparticles have been widely used for foodborne pathogen detection (Escalante-Maldonado et al., 2015; Sun et al., 2015; Hwang et al., 2016; Luciani et al., 2016; Wang et al., 2016). The labeled antibody is a key point for a successful immunomagnetic detection method, and a limiting step is the quality of the anti-pathogen antibody used. The genus Salmonella is especially problematic because it has over 2,600 serotypes, so the probability of false negative may be high (Eng et al., 2015). In addition, the cost of superior anti-bacteria antibodies was always very high.

Developments in molecular biology, genomics, and bioinformatics now enable specific nucleotide sequences to be developed as barcodes for detection of target pathogens. Furthermore, the nucleotide sequence adjacent to the pathogen-specific barcode can also be used as a medium to purify the detection sequence. For example, magnetic nanoparticles labeled with complementary sequences were used to capture target DNA sequences containing barcodes of Listeria monocytogenes followed by amplification and identification by polymerase chain reaction 
(PCR) (Amagliani et al., 2004). They further used magnetic capture probes to simultaneously isolate Salmonella and L. monocytogenes DNA from seafood and detected the barcodes by triplex real-time PCR (Amagliani et al., 2010). However, since genomic DNA maintains a double helical structure, even when genomic DNA was denatured, the sensitivity would be compromised because of the large size of the genomic DNA.

Alternatively, the use of mRNA, which is single-stranded and much smaller than genomic DNA, for oligonucleotide hybridization may improve the procedure. The stability of DNA:RNA hybrids is also substantially greater than those of DNA:DNA duplexes (Casey and Davidson, 1977). Moreover, mRNA is considered as a more appropriate target than DNA to assess cell viability because mRNA have a short half-life, only a few minutes (Coutard et al., 2005; Liu et al., 2010), and is generally present only in viable cells (Garcia et al., 2010). That is, only viable cells could be detected using RNA-based detection methods (Zhou et al., 2014), which is the true harmful risk to food safety.

In previous research, we found nanoparticles affected PCR primarily via surface interactions with PCR components, and if the surface was blocked, the inhibition effect would be eliminated (Bai et al., 2015). Therefore, we proposed to directly add the complexes of magnetic capture probes and the captured target sequences in RT-qPCR to detect Salmonella, seeking to reduce operation steps and target losses, save time, and enhance sensitivity.

In this study, we prepared magnetic capture probes by modifying oligonucleotides complementary to target sequences on the surface of amino-modified silica-coated magnetic nanoparticles and optimized the conditions and parameters of probe synthesis and hybridization. We used the magnetic capture probes to separate invA mRNA, with the novel step of putting the complexes of magnetic capture probes and invA mRNA into RT-qPCR mixture without any denaturation and purification steps, to detect Salmonella in milk.

\section{MATERIALS AND METHODS}

\section{Reagents}

Glutaraldehyde, 4-(N-Maleimidomethyl) cyclohexane-1-carboxylic acid 3-sulfo-N-hydroxysuccinimide ester sodium salt (SMCC),
Triton X-100, lysozyme, and proteinase K were purchased from Sigma-Aldrich (St. Louis, MO, USA). $2 \times$ SYBR Green PCR mix was obtained from TaKaRa (Dalian, China). All preparations and measurements were carried out in sterilized Millipore water. PCR primer pairs and oligonucleotides were synthesized by Shanghai Biotech (Shanghai, China). The detailed information was shown in Table 1. All the oligonucleotides and primer pairs were designed for this study except the primers pair InvA-f/r used for invA of Salmonella that have been previously described (Jiang et al., 2013).

\section{Strains and Cultivation}

The Guangdong Institute of Microbiology (Guangdong, China) provided Salmonella enterica (ATCC 13076). Salmonella was cultivated using Luria-Bertani medium (Becton Dickinson, MD, USA). Milk was obtained from a local dairy and tested negative for Salmonella by selective plating and PCR methods before use.

\section{Synthesis and Analysis of Amino-Modified Silica-Coated $\mathrm{Fe}_{3} \mathrm{O}_{4}$ Magnetic Nanoparticles}

$\mathrm{Fe}_{3} \mathrm{O}_{4}$ magnetic nanoparticles, which were prepared using the co-precipitation method (Bai et al., 2015), were coated with silica and modified with amino groups by the reverse microemulsion method (Bai et al., 2016). ASMNPs morphologies were observed and analyzed by transmission electron microscopy (TEM) using a JEM-2010HT instrument (JEOL, Japan). The particles were sonicated for $1 \mathrm{~min}$, and $10 \mu \mathrm{l}$ of the solution was placed on a 200 mesh copper grid and then dried at room temperature. The grid was used for TEM analysis.

\section{Preparation of Magnetic Capture Probes}

Two methods were used to label capture oligonucleotides on the ASMNPs surfaces based on the previous reports (Nam et al., 2004; Bruce and Sen, 2005). The schematic diagrams were shown in Figure 1.

Method 1: ASMNPs (2 mg) were dispersed in $1 \mathrm{ml}$ phosphate buffered saline (PBS) buffer containing $200 \mu \mathrm{g}$ SMCC, pH 7.4. After shaking for $8 \mathrm{~h}$, the pellets were dispersed in $1 \mathrm{ml}$ of Capture Oligonucleotide 2 solution $(10 \mu \mathrm{mol} / \mathrm{L})$ and shaken overnight at room temperature. The pellets were blocked with $10 \%$ skimmed milk powder solution for $8 \mathrm{~h}$ and dispersed in

TABLE 1 | Oligonucleotides and primer pairs in this study.

DNA sequence $\left(5^{\prime}\right.$ to $\left.3^{\prime}\right)$

Capture oligonucleotides

Capture Oligonucleotides 1

Capture Oligonucleotides2

Capture Oligonucleotides3

Long oligonucleotides

Long Oligonucleotides 1

Long Oligonucleotides2

Primer pairs

Lolig-f/r

InvA-f/r

\begin{abstract}
$\mathrm{NH}_{2}$-TाIIIIIII ATTCCGCCGTGTATCGTAATTGAGT
HS-TIIIIIIIIIITATTCCGCCGTGTATCGTAATTGAGT

ACAGTACCGCAGGAAACGTTGTIIIIIIIIIITT'-SH
\end{abstract}

GAAGAGATITAGCGCAGTGTAGCATTACTGGATACTGCGATTATTGAACTCAATTACGATACACGGCGGAAT

GAAGAGATITAGCGCAGTGTAGCATTACTGGATACTGCGATTATTGAACTCAATTACGATACACGGCGGAATITIIIIIIIT-SH

GAAGAGATITIAGCGCAGTGTAG; CATTACTGGATACTGCGATTATTGA

ACAGTGCTCGTTIACGACC; ACTGGTACTGATCGATAAT 
Method 1:

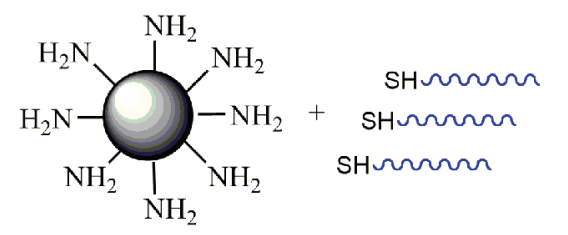

ASMNP

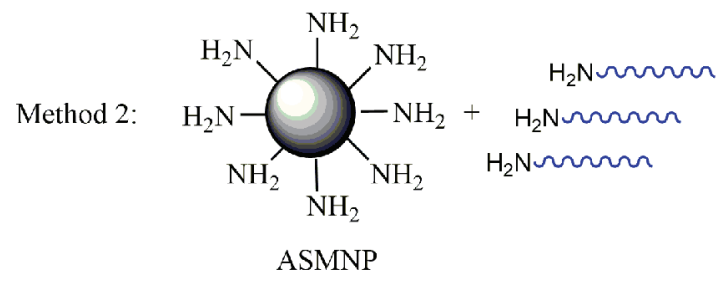

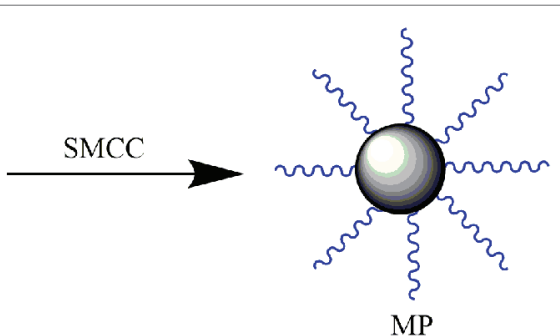

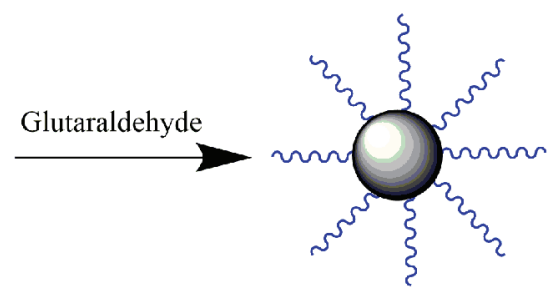

$\mathrm{MP}^{\prime}$

FIGURE 1 | The schematic diagrams of preparation of SMCC-based MP and glutaraldehyde-based MP'.

PBS buffer containing 2\% BSA and $0.1 \%$ sodium azide. The final magnetic capture probe was named MP.

Method 2: ASMNPs ( $2 \mathrm{mg}$ ) were dispersed in $1 \mathrm{ml}$ phosphate buffered saline (PBS) containing 5\% glutaraldehyde ( $\mathrm{pH} 7.4$ ). The magnetic pellets were washed with PBS to remove free glutaraldehyde after shaking for $3 \mathrm{~h}$, and the pellets were suspended in $500 \mu \mathrm{l}$ PBS containing $200 \mu \mathrm{l}$ Capture Oligonucleotide1 solution $(10 \mu \mathrm{mol} / \mathrm{L})$ and incubated overnight at room temperature. The magnetic pellets were blocked with $100 \mu \mathrm{l}$ of $10 \%$ skimmed milk powder solution (Solarbio, Shanghai, China) and suspended in PBS containing 2\% BSA and $0.1 \%$ sodium azide. The final magnetic capture probe was named $\mathrm{MP}^{\prime}$.

\section{Capture Using Magnetic Capture Probes}

Samples were pretreated based on a modification method of published procedures (Amagliani et al., 2004; Bai et al., 2013). In brief, artificially contaminated milk samples $(10 \mathrm{ml})$ were centrifuged at $6000 \times \mathrm{g}$ for $20 \mathrm{~min}$ at $4^{\circ} \mathrm{C}$, and the pellets were suspended in $1 \mathrm{ml}$ of RNAprotect Bacteria Reagent (Qiagen, Germany). They were then incubated for $5 \mathrm{~min}$ and centrifuged at $9400 \times \mathrm{g}$ for $10 \mathrm{~min}$. The pellets were suspended in $50 \mu \mathrm{l}$ of $50 \mathrm{mg} / \mathrm{ml}$ lysozyme, $50 \mu \mathrm{l}$ of $20 \mathrm{mg} / \mathrm{ml}$ proteinase $\mathrm{K}$, and $10 \mu \mathrm{l}$ of Triton $\mathrm{X}-100$ and incubated at $37^{\circ} \mathrm{C}$ for $15 \mathrm{~min}$. Trizol (Invitrogen, Carlsbad, CA, USA) was added $(1 \mathrm{ml})$ and the solution was incubated for $5 \mathrm{~min}$ at room temperature. Chloroform $(250 \mu \mathrm{l})$ was added and the solution was vortexed for $15 \mathrm{~s}$. After centrifugation at $9600 \times \mathrm{g}$ for $10 \mathrm{~min}$, the upper layer (aqueous phase) was transferred to a new $1.5 \mathrm{ml}$ tube and incubated with $50 \mu \mathrm{g}$ magnetic capture probes labeled with Capture Oligonucleotides3, which was partly complementary to invA mRNA, for $15 \mathrm{~min}$ at room temperature. The pellets were magnetically separated and mixed with $2.5 \mu \mathrm{l}$ of $10 \mathrm{X}$ DNase buffer and $1 \mu$ l of DNase (Takara, Dalian, China) then incubated at $37^{\circ} \mathrm{C}$ for $20 \mathrm{~min}$. The reaction was stopped by heating at $80^{\circ} \mathrm{C}$ for $2 \mathrm{~min}$ after the addition of $2.5 \mu \mathrm{l}$ of $0.5 \mathrm{~mol} / \mathrm{L}$ EDTA. The pellets were washed with DEPC-treated water and then used as templates in RT-qPCR.

\section{QPCR and RT-qPCR Amplification}

Quantitative PCR (qPCR) was performed using $25 \mu$ l reaction volumes containing $1 \mu \mathrm{l}$ of DNA template, 5 pmol of each primer, and $12.5 \mu \mathrm{l}$ of $2 \times \mathrm{SYBR}^{\circledR}$ Green PCR master mix (TaKaRa, Dalian, China). PCR thermocycling was as follows: $2 \mathrm{~min}$ at $95^{\circ} \mathrm{C}, 40$ cycles of $15 \mathrm{~s}$ at $95^{\circ} \mathrm{C}, 15 \mathrm{~s}$ at $60^{\circ} \mathrm{C}$, and $20 \mathrm{~s}$ at $72^{\circ} \mathrm{C}$. Amplifications were carried out using a Mastercycler ${ }^{\circledR}$ ep realplex instrument (Eppendorf, Germany). RT-qPCR was performed using a One Step PrimeScript RT-qPCR Kit (TaKaRa, Dalian, China) according to the manufacturer's instructions.

\section{RESULTS}

\section{Optimization of Magnetic Capture Probes}

The spherical amino-modified silica-coated $\mathrm{Fe}_{3} \mathrm{O}_{4}$ magnetic nanoparticles we synthesized appeared rough (Figure 2), different to the particles with smooth surfaces in previous reports (Bai et al., 2016). In our previous study, we found that this rough surface may be the reason for the large number of surface amino groups available for coupling (Bai et al., 2016). Using magnetic nanoparticles with many more amino groups was a basic strategy to maximize the capture efficiency of probes. Additionally, binding more capture oligonucleotides to the amino groups is another critical step.

There are two basic strategies to label the oligonucleotides on ASMNPs. One strategy is to use SMCC as a coupling agent to covalently immobilize the thiol-modified oligonucleotides (Capture Oligonucleotides1) on the surface of ASMNPs (the 


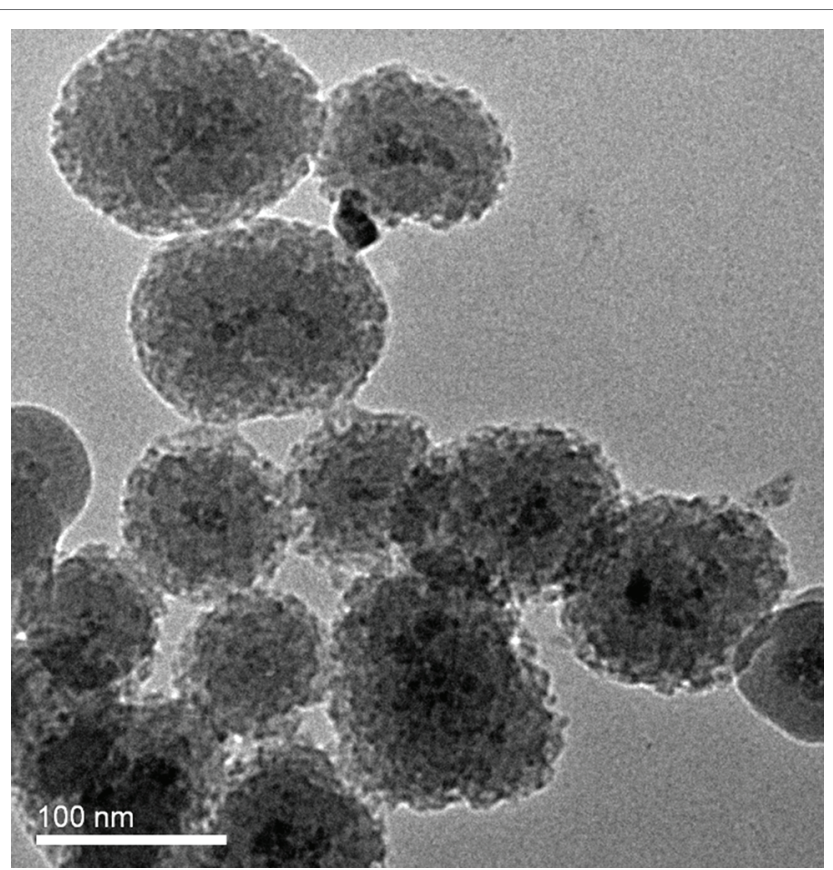

FIGURE 2 | TEM image of ASMNPs synthesized for this study.

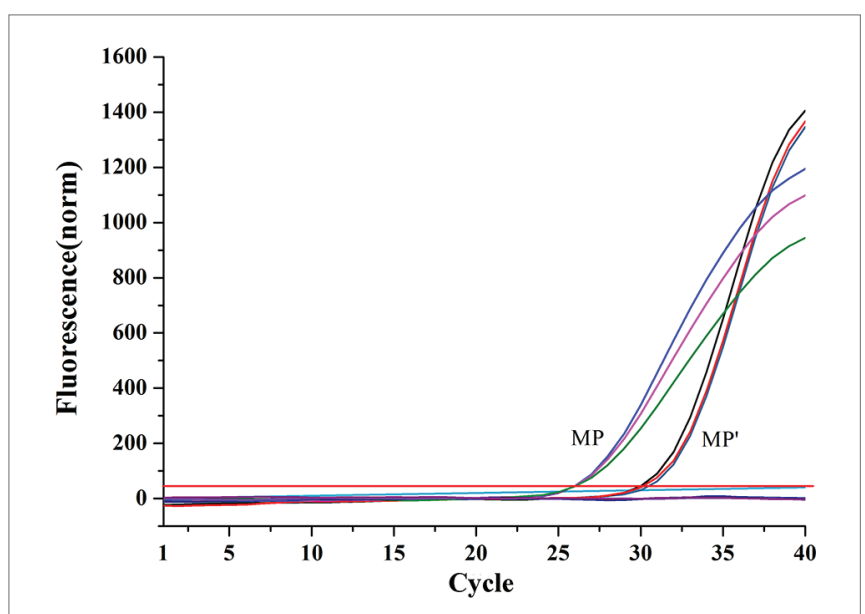

FIGURE 3 | Comparison of the capture capabilities of two magnetic capture probes based on qPCR assays (MP: magnetic capture probe prepared using Method 1; MP': magnetic capture probe prepared using Method 2).

final magnetic capture probe was named MP); another strategy is to use glutaraldehyde as a coupling agent to covalently immobilize the amino-modified oligonucleotides (Capture Oligonucleotides2) to ASMNPs (the final magnetic capture probe was named $\mathrm{MP}^{\prime}$ ). The schematic diagrams were shown in Figure 1. We used Long Oligonucleotides1 whose $3^{\prime}$ end was complementary to Capture Oligonucleotides 1 as target to compare the capture efficiency of these two types of probes.

Twenty micrograms of each of these two magnetic probes were used to capture the same amount of target $(1 \mathrm{ml}$ of Long
Oligonucleotides1). And then the magnetic pellets were used as DNA templates for qPCR. The results of qPCR (Figure 3) showed that the magnetic capture probes prepared using SMCC had higher separation efficiency $(n=3, p<0.05)$, and combined with the calibration curve $\left(\mathrm{y}=-3.1654 \mathrm{x}+40.455, R^{2}=0.9923\right)$ which was established based on Ct values of qPCR using a set of Long Oligonucleotides1solutions of known concentration, the capture capability of MP was 67.4 times than $\mathrm{MP}^{\prime}$. Therefore, we used the probes based on SMCC-strategy in the following experiments.

\section{Evaluation of the Amount of Oligonucleotides Immobilized on the Surface of ASMNPs}

It is inaccurate to evaluate the number of capture sequences immobilized on the surface of ASMNPs by counting the number of the captured target ssDNA because not all of the capture sequences would hybridize with the target sequences. To obtain more direct data, we immobilized the longer thiol-modified oligonucleotides (Long Oligonucleotides2) on the surface of ASMNPs. We could therefore roughly estimate the amount of immobilized capture sequences by qPCR. Twenty micrograms of magnetic capture probes were used as templates for qPCR resulting in a $\mathrm{Ct}$ value of $23.39(n=3)$. According to the calibration curve $\left(y=-5.564 x+86.311, R^{2}=0.9988\right)$ which was obtained based on the serial dilution of Long Oligonucleotides 1 , the amount of capture sequences was $10^{11.3}$ copies per $20 \mu \mathrm{g}$ of magnetic capture probes. In general, the maximum amount of pathogen in culture media could reach $10^{9} \mathrm{CFU} / \mathrm{ml}$. Therefore, under ideal conditions and regardless of the hybridization rate and the recovery of the magnetic capture probes, even $20 \mu \mathrm{g}$ of magnetic capture probes would be sufficient to separate the maximum amount of pathogenderived nucleic acid. In order to further increase the probability of capture, $50 \mu \mathrm{g}$ was used in the practical application.

\section{Effects of Magnetic Capture Probes on Polymerase Chain Reaction}

In previous studies, target sequences were always denatured from magnetic capture probes and tediously purified before PCR (Jacobsen and Holben, 2007). In an attempt to optimize sensitivity and detection speed, we planned to directly add the complexes of probes and target sequences in qPCR as templates. However, firstly we needed to identify whether the magnetic capture probes would inhibit qPCR. We varied the amounts to determine the maximum that we could add without inhibiting qPCR. Magnetic capture probes $(0,20$, $40,60,80$, and $100 \mu \mathrm{g}$ ) were added to qPCR mixtures. Though maximum fluorescence decreased with an increase of magnetic capture probes added, probably because the magnetic probes quenched part of fluorescence of SYBR Green, the Ct values were unaffected by the addition of 20,40 , and $60 \mu \mathrm{g}(n=3$; $p>0.1)$. At the higher levels $(80$ and $100 \mu \mathrm{g})$, the $\mathrm{Ct}$ values increased slightly $(n=3, p>0.05$; Figure 4$)$. The results showed that when the amount of magnetic capture probes added in qPCR was under $60 \mu \mathrm{g}$, the amplification was not affected. 


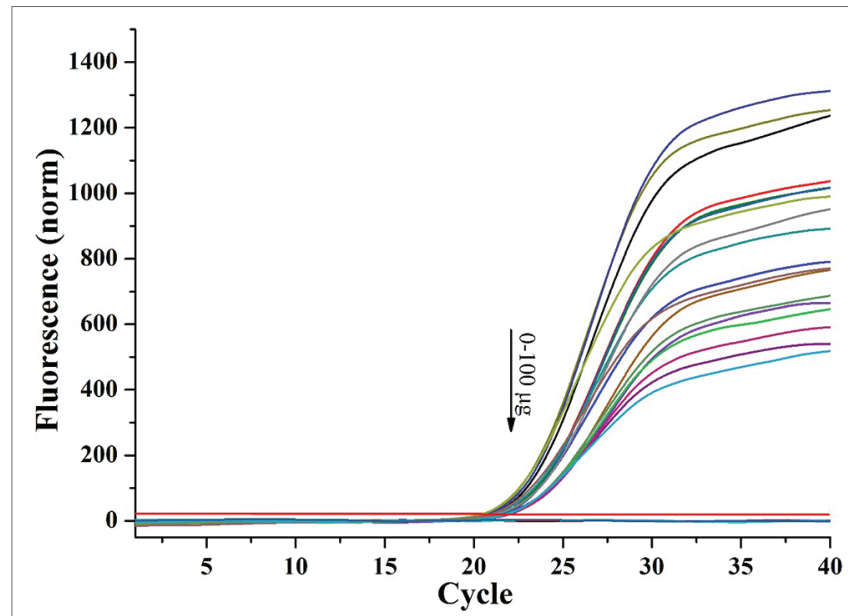

FIGURE 4 | Effect of magnetic capture probe on qPCR (DNA templates: $5 \mu$ l of $8.359 \mathrm{ng} / \mu \mathrm{l}$ long oligonucleotides1).

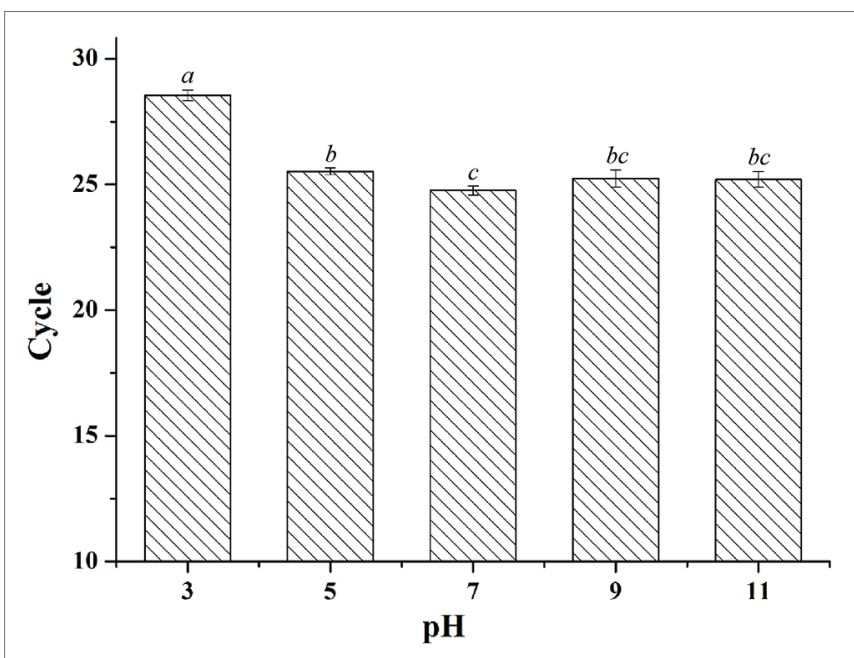

FIGURE 5 | The effect of pH on capture capability of magnetic probes.

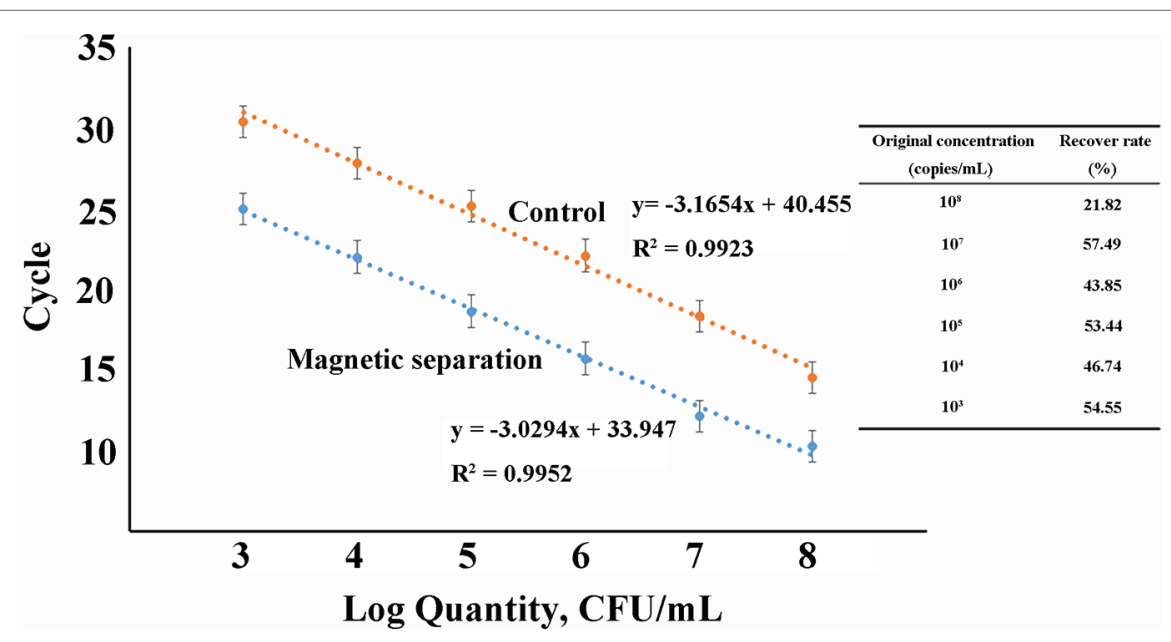

FIGURE 6 | The capture capacity of magnetic probes for artificial long oligonucleotides (Inset: recover rate in solutions with different concentrations).

\section{Effect of pH on Hybridization Rate}

The $\mathrm{pH}$ of hybridization systems may vary with sample type so we investigated whether $\mathrm{pH}$ affected the hybridization rate between the capture sequences and target sequences. Before hybridization, the solutions containing the same amount of Long Oligonucleotides1 were adjusted to different $\mathrm{pH}$ with sodium hydroxide and hydrochloric acid. After hybridization and magnetic separation, the pellets were washed with TE buffer and then used as qPCR templates. The hybridization was severely affected only at low $\mathrm{pH}(\mathrm{pH} 3)$, and there were only slight effects at other levels (Figure 5). That is, even when the solution was treated with Trizol ( $\mathrm{pH}$ ), the hybridization would not be much affected.

\section{Capture Capacity of Magnetic Capture Probes for Long Oligonucleotides1}

In order to evaluate the capture capacity of the magnetic capture probes for isolating the target sequences, we used the Long Oligonucleotides1 as a model. These contained sequences for both hybridization capture and qPCR detection. The oligonucleotides were serially diluted 10 -fold and $20 \mu \mathrm{g}$ of magnetic capture probe was hybridized with the targets. All recovery rates were near $50 \%$ except for the solution whose original concentration was $10^{8}$ copies $/ \mathrm{ml}$ (recovery rate $=22 \%)(n=3, p<0.05$; Figure 6). Although $20 \mu \mathrm{g}$ of magnetic capture probes might contain more than $10^{11.3}$ copies of capture sequences based on the previous experiments, they were not sufficient for $10^{8}$ copies of target sequences. The most probable reason for these results was steric hindrance.

\section{Detection of Salmonella in Milk}

We used magnetic capture probes labeled with Capture Oligonucleotides3, which was partly complementary to invA mRNA, to separate the invA mRNA in the milk contaminated 

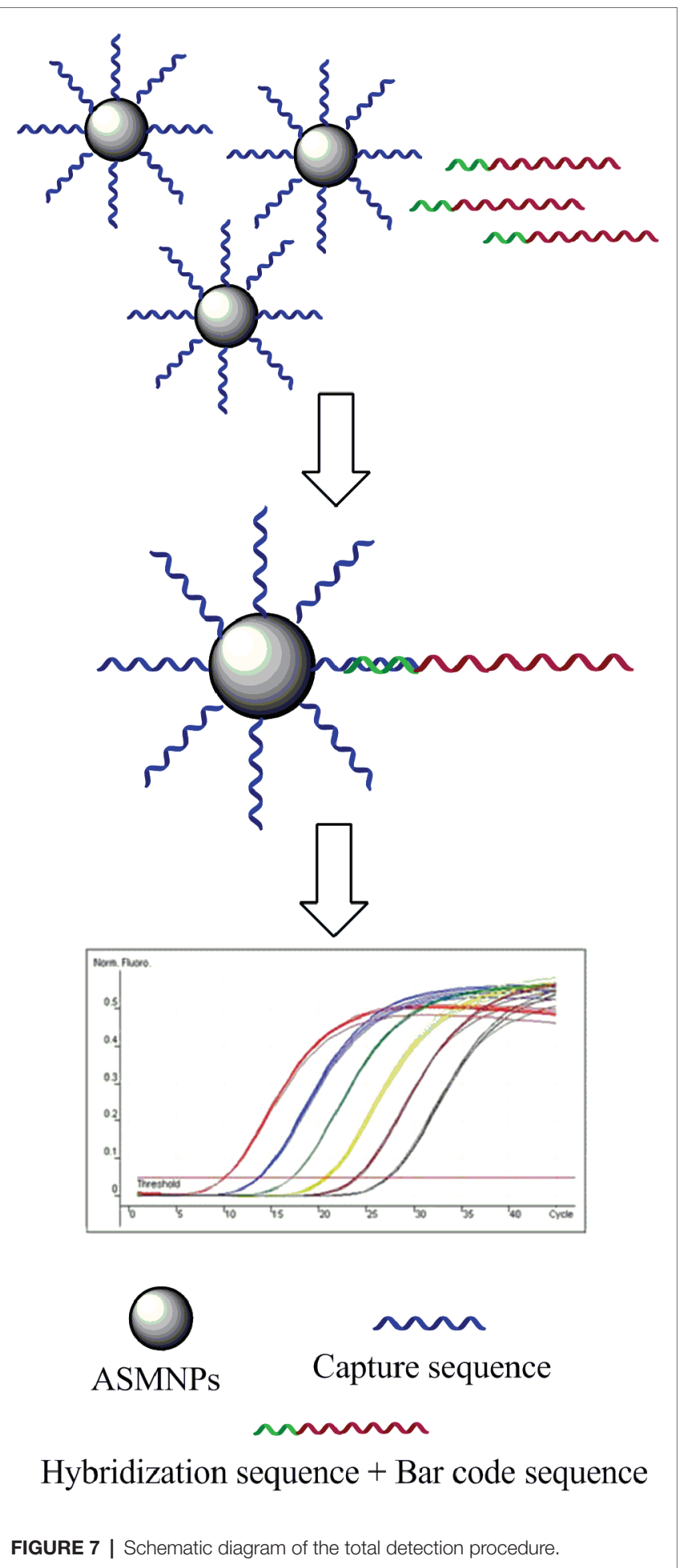

artificially with 10-fold diluted Salmonella and then detected the invA mRNA by RT-qPCR. The schematic diagram was shown in Figure 7. The milk was processed according to 2.5; in this case, the target mRNA was released into the solution. When the magnetic capture probes were added, the labeled sequences would hybridize with invA mRNA. After magnetic separation and rinse, the magnetic pellets were used to do

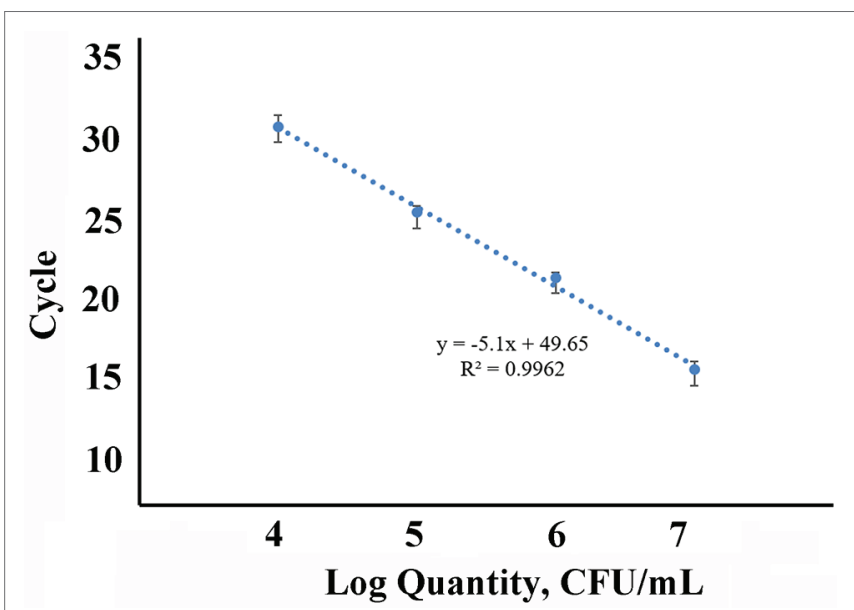

FIGURE 8 | Sensitivity of the detection for Salmonella in artificially contaminated milk.

TABLE 2 | Detection of Salmonella in artificially contaminated milk.

\begin{tabular}{llllll}
\hline $\begin{array}{l}\text { Inoculum } \\
\text { (CFU/ml) }\end{array}$ & \multicolumn{5}{c}{ Enrichment time (h) } \\
\cline { 2 - 6 } & $\mathbf{0}$ & $\mathbf{6}$ & $\mathbf{1 2}$ & $\mathbf{1 8}$ & $\mathbf{2 4}$ \\
\hline $10^{-1}$ & - & - & - & - & - \\
$10^{0}$ & - & - & + & + & + \\
$10^{1}$ & - & - & + & + & + \\
$10^{2}$ & - & - & + & + & + \\
\hline
\end{tabular}

TABLE 3 | Specificity of the method based on extraction of mRNA using magnetic capture probes and RT-qPCR.

\begin{tabular}{|c|c|c|c|c|c|}
\hline \multicolumn{3}{|c|}{ Salmonella strains } & \multicolumn{3}{|c|}{ Non-Salmonella strains } \\
\hline Organism & Number & Result & Organism & Number & Result \\
\hline $\begin{array}{l}\text { Salmonella } \\
\text { typhimurium }\end{array}$ & 5 & + & $\begin{array}{l}\text { Staphylococcus } \\
\text { aureus }\end{array}$ & 3 & \\
\hline $\begin{array}{l}\text { Salmonella } \\
\text { choleraesuis }\end{array}$ & 4 & + & $\begin{array}{l}\text { Listeria } \\
\text { monocytogenes }\end{array}$ & 2 & - \\
\hline $\begin{array}{l}\text { Salmonella } \\
\text { enteritidis }\end{array}$ & 3 & + & $\begin{array}{l}\text { Vibrio } \\
\text { parahaemolyticus }\end{array}$ & 1 & - \\
\hline $\begin{array}{l}\text { Salmonella } \\
\text { paratyphi }\end{array}$ & 2 & + & Escherichia coli & 1 & - \\
\hline $\begin{array}{l}\text { Salmonella } \\
\text { infantis }\end{array}$ & 1 & + & $\begin{array}{l}\text { Shigella } \\
\text { dysenteriae }\end{array}$ & 1 & - \\
\hline $\begin{array}{l}\text { Salmonella } \\
\text { tallahassee }\end{array}$ & 1 & + & Bacillus subtilis & 1 & - \\
\hline $\begin{array}{l}\text { Salmonella } \\
\text { vellore }\end{array}$ & 1 & + & $\begin{array}{l}\text { Enterococcus } \\
\text { faecium }\end{array}$ & 1 & - \\
\hline $\begin{array}{l}\text { Salmonella } \\
\text { anatum }\end{array}$ & 1 & + & & & \\
\hline
\end{tabular}

the RT-qPCR assay. The detection limit was $10^{4} \mathrm{CFU} / \mathrm{ml}$ and log-linear relationships occurred from $10^{4}$ to $10^{7} \mathrm{CFU} / \mathrm{ml}$ (Figure 8).

Alternatively, we could enrich the bacteria to get a higher sensitivity. Milk $(25 \mathrm{ml})$ contaminated with Salmonella was combined with $225 \mathrm{ml}$ of Luria-Bertani broth and incubated at $37^{\circ} \mathrm{C}$ for $12 \mathrm{~h}$, then we processed $10 \mathrm{ml}$ of the solution 
as for the milk samples above. The detection limit reached $10 \mathrm{CFU} / \mathrm{ml}$ with a detection rate of $100 \%$ (Table 2).

In addition, 28 bacteria were used to determine the specificity of this method based on extraction of mRNA using magnetic capture probes and RT-qPCR (Table 3). Eighteen Salmonella $\left(10^{4} \mathrm{CFU} / \mathrm{ml}\right)$ which was separated from the food samples and identified by our labs were tested, and all showed positive results. Non-Salmonella bacteria (10 genera, $10^{6} \mathrm{CFU} / \mathrm{ml}$ ) showed negative results (no signal before $32 \mathrm{Ct}$ ). The results were expected because invA gene were proved previously many times to be a specific gene for Salmonella (Wang et al., 2015; Pande et al., 2016), and most of all, in this method, the target mRNA were separated firstly by using magnetic probes; thus, the specificity would be better than those methods in which all of the mRNA was used to convert into cDNA.

\section{DISCUSSION}

Salmonella is the leading cause of bacterial food poisoning in humans worldwide (Zhang et al., 2016; Rahman, 2017). It is reported that more than $90 \%$ of human illness caused by Salmonella is foodborne and results from contaminated meat, eggs, and milk (Foley and Lynne, 2008). Thus, more rapid and reliable methods for the detection of Salmonella are required except the traditional culture methods which take 4-7 days. For culture-independent methods, magnetic separation has been widely used to enrich the targets to realize rapid detection (Brandão et al., 2015). In our previous research, we found ASMNPs could adsorb DNA by hydrogen bond and electrostatic interaction, and thus, we used ASMNPs to separate bacterial genomic DNA and combined it with PCR to rapidly detect Salmonella Enteritidis and L. monocytogenes (Bai et al., 2013). However, pathogen detection via DNA does not differentiate between viable and dead bacteria because DNA from non-viable bacteria also could produce signal. Since mRNA is very labile, it is considered that detection of mRNA is superior to detection based on DNA. Therefore, in this study, we prepared magnetic capture probes to separate mRNA sequences by hybridization and using RT-qPCR in which complexes of probes and target sequences were directly used as template to detect Salmonella.

For improving the separation capability of the magnetic capture probes, on the one hand, we prepared the magnetic nanoparticles with rich amino groups based on previous research (Bai et al., 2016); on the other hand, we selected a superior method, SSMCbased strategy, to couple the oligonucleotides with amino groups to make sure the probes contain more capture sequences.

Further, to reduce the operating steps, save time, and improve sensitivity, we tried to directly add the complexes of magnetic capture probes and target sequences to PCR. In previous research, we found that the bare ASMNPs would inhibit PCR

\section{REFERENCES}

Amagliani, G., Brandi, G., Omiccioli, E., Casiere, A., Bruce, I., and Magnani, M. (2004). Direct detection of Listeria monocytogenes from milk by magnetic based DNA isolation and PCR. Food Microbiol. 21, 597-603. doi: 10.1016/j.fm.2003.10.008 by adsorbing PCR components and the amplification would be normal after the surface of ASMNPs were blocked. The magnetic capture probes were also blocked by capture sequences and proteins; thus, appropriate amount of probes could not affect PCR amplification. Moreover, the magnetic capture probes separated mRNA sequences would work in the solution containing Trizol ( $\mathrm{pH}$ 5.0) in order to simplify the mRNA isolation steps. In this case, the effect of $\mathrm{pH}$ on the hybridization rate should be evaluated. After comparing different $\mathrm{pH}$ conditions, we found there was only slight effect for hybridization at $\mathrm{pH} 5$.

The magnetic capture probes were used to isolate the invA mRNA in milk artificially contaminated with Salmonella, and the invA mRNA was then detected by RT-qPCR. The detection limit was $10^{4} \mathrm{CFU} / \mathrm{ml}$ (about $30 \mathrm{Ct}$ ). At the same time, we noted that a Ct value (about 32) existed with no Salmonella added to the milk. Though we could confirm this was caused by the magnetic capture probes, the detailed reason is still not clear and needed to be explored in future research. That is, if we clearly know that why the magnetic capture probes caused a false positive signal at 32 cycles in RT-qPCR without target mRNA, maybe we could realize a lower detection limits. But even so, the current detection limit was superior. Fey et al. reported that the detection limits were $5 \times 10^{4}$ and $5.5 \times 10^{4}$ copies (invA gene) in drinking and pond water, respectively (Fey et al., 2004). In this research, the sample was milk which was more complex than water. Most of all, this method was more rapid and simple to extract target mRNA. Alternatively, after cultivation for $12 \mathrm{~h}$, the detection rate was $100 \%$ even though the milk contained only $10 \mathrm{CFU} / \mathrm{ml}$ of Salmonella. This result was also superior to our previous research extracting mRNA based on the traditional method. In our previous research (Zhou et al., 2014), the samples must be cultivated for $18 \mathrm{~h}$ to detect $10 \mathrm{CFU} / \mathrm{ml}$ of Salmonella.

\section{AUTHOR CONTRIBUTIONS}

YB designed and initiated the study, interpreted the results, and wrote the manuscript. YC and XS contributed to improvement of the manuscript. YS, CS, and DW contributed to analysis of the data and discussion of the results. XS designed the outline of this study and manuscript and provided laboratory equipment and space.

\section{FUNDING}

This study was supported by the National Key R\&D Program of China (grant number 2016YFE0106100) and Shanghai Municipal Natural Science Foundation (grant number 18ZR1425500). 
amino-modified silica-coated magnetic nanoparticles as a main model. ACS Appl. Mater. Interfaces 7, 13142-13153. doi: 10.1021/am508842v

Bai, Y., Cui, Y., Paoli, G. C., Shi, C., Wang, D., Zhou, M., et al. (2016). Synthesis of amino-rich silica-coated magnetic nanoparticles for the efficient capture of DNA for PCR. Colloids Surf. B Biointerfaces 145, 257-266. doi: 10.1016/j.colsurfb.2016.05.003

Bai, Y., Song, M., Cui, Y., Shi, C., Wang, D., Paoli, G. C., et al. (2013). A rapid method for the detection of foodborne pathogens by extraction of a trace amount of DNA from raw milk based on amino-modified silica-coated magnetic nanoparticles and polymerase chain reaction. Anal. Chim. Acta 787, 93-101. doi: 10.1016/j.aca.2013.05.043

Brandão, D., Liébana, S., and Pividori, M. I. (2015). Multiplexed detection of foodborne pathogens based on magnetic particles. New Biotechnol. 32, 511-520. doi: 10.1016/j.nbt.2015.03.011

Bruce, I. J., and Sen, T. (2005). Surface modification of magnetic nanoparticles with alkoxysilanes and their application in magnetic bioseparations. Langmuir 21, 7029-7035. doi: 10.1021/la050553t

Casey, J., and Davidson, N. (1977). Rates of formation and thermal stabilities of RNA: DNA and DNA: DNA duplexes at high concentrations of formamide. Nucleic Acids Res. 4, 1539-1552. doi: 10.1093/nar/4.5.1539

Coutard, F., Pommepuy, M., Loaec, S., and Hervio-Heath, D. (2005). mRNA detection by reverse transcription-PCR for monitoring viability and potential virulence in a pathogenic strain of Vibrio parahaemolyticus in viable but nonculturable state. J. Appl. Microbiol. 98, 951-961. doi: 10.1111/j.1365-2672.2005.02534.x

Eng, S. K., Pusparajah, P., Mutalib, N. S. A., Ser, H. L., Chan, K. G., and Lee, L. H. (2015). Salmonella: a review on pathogenesis, epidemiology and antibiotic resistance. Front. Life Sci. 8, 1-10. doi: 10.1080/21553769.2015.1051243

Escalante-Maldonado, O., Kayali, A. Y., Yamazaki, W., Vuddhakul, V., Nakaguchi, Y., and Nishibuchi, M. (2015). Improvement of the quantitation method for the tdh+ Vibrio parahaemolyticus in molluscan shellfish based on most probable number, immunomagnetic separation, and loop-mediated isothermal amplification. Front. Microbiol. 6:270. doi: 10.3389/fmicb.2015.00270

Fey, A., Eichler, S., Flavier, S., Christen, R., Höfle, M. G., and Guzmán, C. A. (2004). Establishment of a real-time PCR-based approach for accurate quantification of bacterial RNA targets in water, using Salmonella as a model organism. Appl. Environ. Microbiol. 70, 3618-3623. doi: 10.1128/AEM.70.6.3618-3623.2004

Foley, S. L., and Lynne, A. M. (2008). Food animal-associated Salmonella challenges: pathogenicity and antimicrobial resistance. J. Anim. Sci. 86, 173-187. doi: 10.2527/jas.2007-0447

Garcia, R., Baelum, J., Fredslund, L., Santorum, P., and Jacobsen, C. S. (2010). Influence of temperature and predation on survival of Salmonella enterica Serovar Typhimurium and expression of $i n v A$ in soil and manureamended soil. Appl. Environ. Microbiol. 76, 5025-5031. doi: 10.1128/ aem.00628-10

Hwang, J., Kwon, D., Lee, S., and Jeon, S. (2016). Detection of Salmonella bacteria in milk using gold-coated magnetic nanoparticle clusters and lateral flow filters. RSC Adv. 6, 48445-48448. doi: 10.1039/c6ra05446c

Jacobsen, C. S., and Holben, W. E. (2007). Quantification of mRNA in Salmonella sp. seeded soil and chicken manure using magnetic capture hybridization RT-PCR. J. Microbiol. Methods 69, 315-321. doi: 10.1016/j. mimet.2007.02.001

Jiang, Q., Fu, B., Chen, Y., Wang, Y., and Liu, H. (2013). Quantification of viable but nonculturable bacterial pathogens in anaerobic digested sludge. Appl. Microbiol. Biotechnol. 97, 6043-6050. doi: 10.1007/s00253-012-4408-2

Liu, Y. M., Wang, C., Fung, C., and Li, X. F. (2010). Quantification of viable but nonculturable Escherichia coli $\mathrm{O} 157: \mathrm{H} 7$ by targeting the rpoS mRNA. Anal. Chem. 82, 2612-2615. doi: 10.1021/ac1003272

Luciani, M., Di Febo, T., Zilli, K., Di Giannatale, E., Armillotta, G., Manna, L., et al. (2016). Rapid detection and isolation of Escherichia coli O104:H4 from milk using monoclonal antibody-coated magnetic beads. Front. Microbiol. 7:942. doi: $10.3389 /$ fmicb.2016.00942

Nam, J. M., Stoeva, S. I., and Mirkin, C. A. (2004). Bio-bar-code-based DNA detection with PCR-like sensitivity. J. Am. Chem. Soc. 126, 5932-5933. doi: $10.1021 /$ ja 049384

Pande, V. V., Devon, R. L., Sharma, P., McWhorter, A. R., and Chousalkar, K. K. (2016). Study of Salmonella Typhimurium infection in laying hens. Front. Microbiol. 7:203. doi: 10.3389/fmicb.2016.00203

Rahman, H. S. (2017). Salmonella infection: the common cause of human food poisoning. Prog. Biosci. Bioeng. 1, 5-10. doi: 10.29269/pbb2017.vli1.5

Sun, Q., Zhao, G., and Dou, W. (2015). A nonenzymatic optical immunoassay strategy for detection of Salmonella infection based on blue silica nanoparticles. Anal. Chim. Acta 898, 109-115. doi: 10.1016/j.aca.2015.09.041

Wang, D., Wang, Z., Chen, J., Kinchla, A. J., and Nugen, S. R. (2016). Rapid detection of Salmonella using a redox cycling-based electrochemical method. Food Control 62, 81-88. doi: 10.1016/j.foodcont.2015.10.021

Wang, Y., Wang, Y., Luo, L., Liu, D., Luo, X., Xu, Y., et al. (2015). Rapid and sensitive detection of Shigella spp. and Salmonella spp. by multiple endonuclease restriction real-time loop-mediated isothermal amplification technique. Front. Microbiol. 6:1400. doi: 10.3389/fmicb.2015.01400

Zhang, W. H., Lin, X. Y., Xu, L., Gu, X. X., Yang, L., Li, W., et al. (2016). CTX-M-27 producing Salmonella enterica Serotypes Typhimurium and indiana are prevalent among food-producing animals in China. Front. Microbiol. 7:436. doi: $10.3389 /$ fmicb.2016.00436

Zhou, M., Yang, J., Zhou, X., Liu, B., Liu, D., Yuan, C., et al. (2014). Development of a sigDE-based real-time reverse-transcriptase PCR for the detection of viable Salmonella enterica. Foodborne Pathog. Dis. 11, 537-544. doi: 10.1089/ fpd.2013.1701

Conflict of Interest Statement: The authors declare that the research was conducted in the absence of any commercial or financial relationships that could be construed as a potential conflict of interest.

Copyright (c) 2019 Bai, Cui, Suo, Shi, Wang and Shi. This is an open-access article distributed under the terms of the Creative Commons Attribution License (CC BY). The use, distribution or reproduction in other forums is permitted, provided the original author(s) and the copyright owner(s) are credited and that the original publication in this journal is cited, in accordance with accepted academic practice. No use, distribution or reproduction is permitted which does not comply with these terms. 